\title{
Determinants of Career Choice among Students of Institute of Chartered Accountants (Ghana)
}

\author{
Justice Stephen Tetteh Zotorvie (MSc) \\ Department of Accounting and Finance, Ho Technical University, Ghana \\ doi: 10.19044/esj.2016.v12n31p255 URL:http://dx.doi.org/10.19044/esj.2016.v12n31p255
}

\begin{abstract}
The main purpose of this study was to investigate the major factors that influence the career choice among the professional level students of the Institute of Chartered Accountants (Ghana). The study also examined the stage or time in the academic life of the students that they decided on accounting as a career. A questionnaire-based survey was the main method used for this study. Exploratory factor analysis and descriptive analysis were employed to determine the key factors influencing the students' career choice in accounting and the timing of the students' decision to choose accounting as a career. The study showed that personal and job prospects factors such as students' interest in accounting, high earnings expectation, availability of jobs, prestige and teacher influence were the most important factors that influence the career choice among students of The Institute of Chartered Accountants (Ghana). Less important factors included influences of advertisement, peers and parents or family members. The study also revealed that majority of the students, $50.2 \%$, made their decision to pursue a career in accounting at the Senior High School level, followed by $18.6 \%$ deciding when they were at Basic School level.
\end{abstract}

Keywords:Accounting profession, Career choice, Chartered Accountants (CA), Professional accounting students, Ghana

\section{Introduction}

Prior studies showed that there has been a considerable decline in the number of tertiary level students studying accounting as a major or career in various parts of the globe over the last decade. [USA (Albrecht \& Sack, 2000; Mauldin et al., 2000); Australia (Jackling, 2002); UK Marshall (2003); New Zealand (Wells \& Fieger, 2005)] as cited by Sugahara \& Boland, (2009) Consequently, researchers who investigated students' career choice in accounting during this period were in part motivated by declining enrolments of accounting studies. According to the American Institute of Certified 
Public Accountants (AICPA), (2013), this declining trend in accounting enrolments appeared to have reversed in the past few years. The AICPA Report, (2013) indicated record numbers of accounting graduates, as well as the highest number of enrolments in undergraduate and graduate accounting programmes, indicating a thriving pipeline of accounting talent (Schiavone, 2013), cited by Djatej et al., (2015). Also, the Financial Reporting Council (FRC), (2015) reported of continuous increase in the number of students of accountancy bodies worldwide. The report revealed that student numbers of accountancy bodies worldwide increased in 2014 by 3\%. The compound annual growth rates of studentship of accountancy bodies worldwide increased by $2.5 \%$ over the period 2010 to 2014. This suggested that the accounting profession continues to remain attractive.

In Ghana, accounting has become one of the preferred career choices for many students who completed secondary or tertiary education. The time series data in Figure 1.1 shows the number of professional level students of The Institute of Chartered Accountant, Ghana (ICAG) from 2008 to 2014. The figure shows a continuous significant growth in studentship over the period.

Figure1.1: Time series data showing (ICAG) professional level students from 2008 to 2014

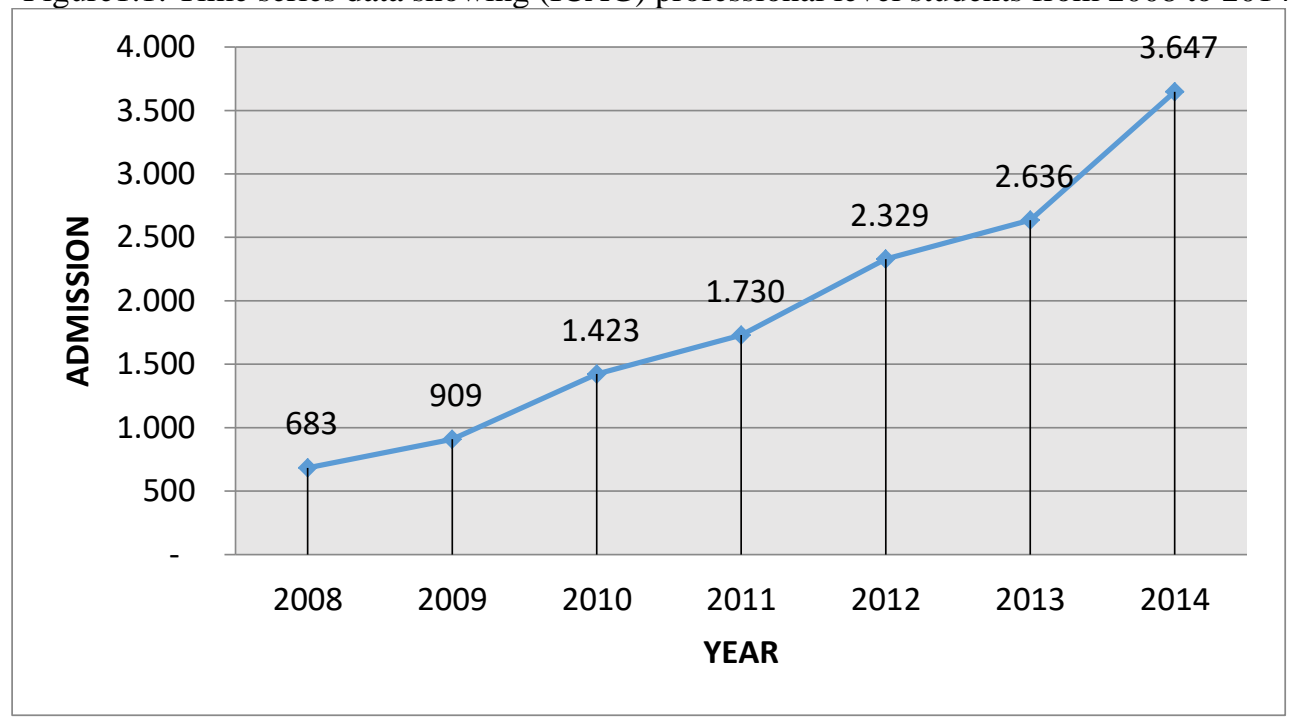

Source: ICA (G) 2014 Annual Report, page 23

More students choosing to become professional accountants were desirable for the future of the accounting profession in Ghana because it was noted by Topan, (2014) that "a career in accounting has the potential to be incredibly rewarding: it could give students the chance to work in virtually any industry and could open up doors they did not even know exist”. 
The question now arises as to what factors influence the students' choice of accounting as a career and at what stage or time in the academic life of students did they decide on accounting as a career? There were different research results regarding the main factors influencing student's career choice in accounting. These could be attributed to jurisdictional factors and the samples used in these studies. Few studies had examined this area using sophomore and senior business students as their sample e.g. Strasser, Ozgur \& Schroeder (2002). Others compared professionals: doctors, lawyers, accountants and engineers e.g. Paollio and Estes (1982), while others used secondary school students e.g. Hashim \& Embong (2015).

A review of extant literature showed that very limited research had been undertaken on determinants of career choice in accounting especially with respect to chartered accountants in Ghana. A recent related study by Ahinful, Paintsil, \& Danquah (2012) focused on students in selected Ghanaian traditional universities who intended to pursue a career in accounting in future. This study was therefore set up to examine the factors which influenced the choice of accounting as a career among the professional students of the Institute of Chartered Accountants (Ghana) and also to determine the stage or time in the academic life of the students that they decided on accounting as a career. These were students who had already made their career choice. Consequently, they would be in a better position to indicate the factors that actually influenced their career choices in accounting. Information obtained from this study may help accounting academics; the professional accounting body and other interest groups in the accounting sector to develop more effective strategies to entice as many students as possible into the accounting profession. The study may also contribute to the literature on career choice of accounting graduates in Ghana, and have implications for the practice and future research in the innovative careers of professional accounting graduates.

\section{Literature Review}

\section{A historical overview of the Accounting Profession in Ghana and the (ICAG)}

Ghana was introduced to British educational system as a former British colony for over a century. During the early years of the colonial period, the managerial personnel, including accountants, for most businesses set up in the country by British investors were generally brought from the UK. At that time, a person could obtain the status of professional accountant only by admission to one of the British professional accounting bodies. Only a small number of local people who could bear the cost of education and training abroad proceeded to England to obtain professional qualifications. 
A landmark for the development of the accountancy profession in British West Africa was the establishment of the Association of Accountants in the Gold Coast (now Ghana) in 1954. Members of this body were mostly Ghanaian accounting students who excelled in both the accounting examinations and practical training requirements of the British professional accounting bodies set up by British investors. They acted as accountants and advisors to the subsequent governments that took the reins of Ghana in matters of accounting and setting accounting standards and regulations (Mbawuni, 2015). This body was transformed to The Institute of Chartered Accountants, Ghana, (ICAG) in 1963 by an Act of Parliament, Act 170 and it is the sole organization in Ghana with the right to award the Chartered Accountant designation, and with the right to regulate the accountancy profession in Ghana, including setting professional standards. The Institute possesses identical traces as the UK accountancy bodies, i.e. ICA (England and Wales) and ICA (Scotland) in terms of similar examinations, training structures and a similar emphasis on auditing as it was done in British (Briston, 1978 cited in Wijewardena \& Yapa, 1998).

In 1978, ICA (England and Wales) gave ICAG full professional independence and freedom after being convinced of ICAG's standards of examination and membership qualifications to be satisfactory and that ICAG could manage its own affairs. There are now two categories of membership, i.e. (a) those who qualify by taking and passing the examinations of the institute and (b) those who are admitted by virtue of their membership of other accountancy bodies so recognized by council. Under group (b) is a large number of Association of Certified Chartered Accountants (ACCA), Institute of Chartered Accountants England and Wales (ICAEW), Chartered Institute of Management Accountants (CIMA) and Certified Public Accountants(CPA). ICAG is also a member of regional and international accounting professional bodies such as Association of Accountancy Bodies in West Africa (ABWA), International Federation of Accountants (IFAC) and Pan-African Federation of Accountants (PAFA).

ICAG conducted its first professional examinations in 1968 under the oversight of ICA (England and Wales). Two out the seven candidates (30\%) passed. Pass rates in the initial four years hovered around two and four. No passes were recorded between 1970 and 1972. However, since 1973, there has been steady increase from six to a little over ninety since 2008 and to two hundred and fifty since 2013.

From a humble beginning of two candidates who passed the Institute's first examination in 1968, ICAG now can boast of 3,923 qualified members out of which 352 are practitioners. The Institute also has a current student population of over 13,000 , with more than 6,000 who regularly sit for the Institutes examinations. 


\section{Determinants of Career Choice in Accounting}

Career choice refers to choosing one occupation over other. According to Sharf (1997) career choice "applies to decisions that individuals make at any point in their career about particular work or leisure activities that they choose to pursue at that time. Ireh (2000) posits that most people, especially the youth have their high school days and even beyond characterized by major career decision making. Career does not only determine the individual's pattern of income but it also affects their personality and concepts in life (Adefolaju, 2015). According to Akomolafe (2003), the individual's career could either make or mar his or her joy and happiness. He further contended that true joy, happiness and satisfaction are linked to proper choice of profession. Thus; the choice of career is a delicate issue and therefore requires caution and serious considerations.

Authors in the field of education and behavioural science tend to attribute different factors that influence accounting career choice among individuals. From the study of Social Cognitive Career Theory (SCCT) developed by Lent, Brown \& Hackett $(1994,1996)$, person, behaviour and environment were identified as key elements that influence career decision making process of an individual. In furtherance to this Betz (1992) and George (2006) in their works established how personal cognition might influence career decision making process. Likewise, individual interest, ability and needs (Chang, 2005).

Ohiwerei \& Nwosu (2009) identified the following external factors as key players in accounting career interest choices: teachers' influence, parental influence, economic and political condition of the country, and peer groups' influence. Reporting their work, Paollio \& Estes (1982) and Umar (2014) also found teacher influence to be more important than parental influence and peer group influence. On the contrary, Strasser, Ozgur \& Schroeder (2002) stated that students value the interest they have in accounting major far more important than the benefits of a career or someone else's influence on them to choose a particular career field. In support of Strasser et al., (2002) further studies also showed that genuine interest in the field is among the most important factors that influence students' career choice (Adams, Pryor \& Adams, 1994, and Umar, 2014).

Felton, Buhr, \& Northey (1994) used the Theory of Reasoned Action (TRA) and found that students selecting a career in chartered accountancy, compared to other professions ranked "long-term earnings" as the most important criterion, followed by "variety in the work" and "flexibility of career options" as the most important factors affecting choice of accounting as the major factor. TRA posits that individuals' career choices are determined by students' intentions which are also influenced by their attitudes and perceptions of social pressure to follow or reject that career. 
Adams, et al., (1994) further showed that good job opportunities and high earnings potential are the most important major-selection factors of 11 listed factors. On the contrary, a study in Australia by Jackling \& Calero (2006) reported that the potential to earn a high salary was not a significant influence on a student's intention to become an accountant but they suggest that it may become important as they progress through their course.

Paollio \& Estes (1982) surveyed professionals: doctors, lawyers, accountants, engineers and found out that availability of employment and earnings potential have a greater impact on career choices for accountants compared to the other professional groups. Umar (2014) again observed that better pay, future prospects and prestige were the major influential factors in career choice in accounting among Nigerian University students. Malgwi, Howe \& Bornaby (2005) opine that monetary incentive is not the only factor influencing career choice in accounting but factors such as career advancement opportunity, prestige, social status, job security, higher earning potential and variety of choices are among the chief factors that have significance in career choice of accounting.

Nonetheless, there are inconsistencies in the results of these studies with some students identifying some factors as important and others not important. For example, per the study of Simons, Lowe \& Stout (2003), it was observed that while Paollilo \& Estes (1982) and Adams, Pryor \& Adams (1994) found availability of job and high earnings to be the most determinant career choice factors, Strasser, Ozgur \& Schroeder (2002) found them to be the least. Instead, they identified interest in subject/field as the most important determining factor. Also, Ohiwerei \& Nwosu (2009) found teacher influence to be more important than parental influence; Mauldin, Crain \& Mounce, (2000) identified parental influence to be so strong as to override the influence of teachers, faculty, and career counsellors, who would likely know more about career fields. Thus, there is an increasing recognition of the need to understand the factors that are 'most' influential in choosing a career in accounting.

\section{Timing of the decision to choose accounting as a career}

Several studies have also examined the timing of the choice-ofaccounting career decision. For example, Paollilo \& Estes (1982) examined the decision time-frame of career choices for four professions, namely practicing accountants, attorneys, physicians and mechanical engineers. They concluded that most mechanical engineers and physicians already decided to follow that career path during their secondary school years, while accountants and attorneys decided on their careers in the first and second years of their tertiary education. A survey conducted by Graves, Nelson \& Deines, (1993) indicated that one- third of students seriously considered a 
career in accounting while in high school. Mauldin et al. (2000) also investigated students' choices of an accounting major and found that the majority of students (41 percent) chose accounting as their major during the first accounting course in college, followed by selection during high school (34 percent). Similar study by Nelson, Vendrsyk, Quirin \& Allen, (2002) also found that the sophomore (second) year of college showed the highest percent of responses to the question, "At what point did you make the decision to majoring in accounting?” The next highest percentage response was "during high school.

\section{Research Methodology Population and Sampling}

The population under study was approximately 13,000 professional level parts one, two and three students of ICA (G) as at 30 ${ }^{\text {th }}$ September 2015. The study involves 445 participants who were conveniently sampled. The study employed a survey method of research. The choice of this method allows for the collection of large amount of data from the population in a highly economical manner. (Saunders, Lewis \& Thornhill, 2007, 138)

\section{Measuring Instrument}

The specific questionnaire used was designed based on the objectives, context and research questions of this study. The questionnaire was closed ended and divided into three sections. Section A contained questions requesting information about the participants' demographic profile. Section B has only one closed-ended question seeking information about the timing of participants' choice-of-accounting career. Section C sought information related to the specific factors that influenced participants' career choice in accounting based on the works of Paolillo \& Estes (1982) and Ali \& Tinggi (2013). It has twenty statements measured with a multiple five-point Likert-type scales that range from 1-(strongly disagree) to 5(strongly agree). The twenty items in this part were mapped onto one of the six major dimensions namely: personal interest, parental/family influence, peer group influence, teacher influence, job prospects, and career awareness programmes. Four items were mapped onto personal interest; three items were mapped onto parental/family influence; three items were mapped onto peer group influence; two items were mapped onto teacher influence; three items were mapped onto job prospects; and five items were mapped onto career awareness programmes. The Cronbach's alpha was used as a measure of reliability. The reliability of the 20-item scale was $\alpha=0.63$, well above the recommended 0.50 level (Kaizer, 1974). 


\section{Data Collection and Analysis}

The questionnaires were personally administered to participants at the following ICA (G) study centres: the ICA (G) School in Accra, Centre for Business Studies (CBS) Accra, Accra Polytechnic (now Accra Technical University) and Ho Polytechnic (now Ho Technical University). These centres were selected because they were perceived as the most popular centres that prepare students for the ICA $(G)$ professional examinations. On all occasions, permission was requested from the subject lecturers and the supervisors of the respective centres involved before administering the questionnaires to the participants. Participation in the survey was voluntary and the participants were assured of confidentiality. The data collected was thoroughly edited by the researcher and codes assigned to non-numeric variables in the data so as to ensure consistency and to check omissions. The Statistical Package for Social Sciences (SPSS) software (version 20) was employed to capture and run the necessary analysis. Exploratory factor analysis was employed to determine the key factors influencing the students' career choice in accounting. The demographic profile of respondents and the timing of students' decision to choose accounting as a career were analysed using descriptive statistics.

\section{Results And Discussion Demographic Profile of Respondents}

Majority of the participants were males at approximately 70\%, whilst $30 \%$ were females. This implies that about $70 \%$ of the times, findings of this research may be attributed to the views of males regarding the determinants of career choice in accounting. The survey revealed that most participants (57.3\%) were in the age group of 26-35 years, followed by the 15-25 years' age group at $29.2 \%$. A small number of the participants at $2.9 \%$ were in the Above 45 year's age brackets. This implies that majority of students of ICA (G) would qualify very early as accountants and be able to practice and derive full benefits from their chosen career before reaching their retirement age. Majority of the participants (52.4\%) were Part Two students, 26.5\% were at their final level, and 21.1\% constitutes Part One students. Three hundred and twelve (312) of participants constituting 70.1\% were in gainful employment while one hundred and thirteen (113) participants constituting 29.9\% were unemployed. 
Table 1: Demographic Profile of Respondents ( $N=445)$

\begin{tabular}{ccc}
\hline Characteristics & (n) Frequency & Percent \\
\hline Gender & 311 & 69.9 \\
Male & 134 & 30.1 \\
Female & 445 & 100 \\
Total & Frequency & Percent \\
Age Group & 130 & 29.2 \\
$15-25$ & 255 & 57.3 \\
$26-35$ & 47 & 10.6 \\
$36-45$ & 13 & 2.9 \\
Above 45 & 445 & 100 \\
Total & Frequency & Percent \\
Current Level of Study & 94 & 21.1 \\
Part One & 233 & 52.4 \\
Part Two & 118 & 26.5 \\
Part Three & 445 & 100 \\
Total & Frequency & Percent \\
Current Employment Status & 312 & 70.1 \\
Employed & 133 & 29.9 \\
Unemployed & 445 & 100 \\
Total & &
\end{tabular}

Source: Author's field data, November 2015

\section{Determinants of Career Choice Decision}

The items influencing the students' choice of career in accounting were subjected to principal components analysis (PCA). Prior to performing PCA the suitability of data for factor analysis was assessed. The correlation matrix among the indicator variables (See Appendix-A) reveals that there exist inter-correlations among the variables, implying that the variables correlate quite highly with one another. The Kaiser-Meyer-Olkin (KMO) measure of sampling adequacy was examined in order to measure the appropriateness of the factor analysis. In the current study, the value of KMO is 0.75 , exceeding the recommended value of 0.6 (Kaiser, p. 1043), which is an indication of sampling adequacy (See Table-2). The Bartlett's test of sphericity is also highly significant with a p-value of 0.000 at a relatively large chi-square value of 3113.73 , supporting the factorability of the correlation matrix.

Table 2: KMO and Bartlett's Test

\begin{tabular}{cc}
\hline Measure & Value \\
\hline KMO Measure of Sampling Adequacy & 0.75 \\
Bartlett's test Critical Value & 3113.73 \\
Bartlett's Test degree of freedom & 190 \\
Bartlett's Test significant value & $.000^{*}$ \\
\hline
\end{tabular}

* Measure of sampling adequacy is significant at 0.01 level

Source: Author’s field data, November 2015 
Factor analysis using principal components procedure with varimax rotation produced six factors with eigenvalues greater than 1.0. The extracted six components explained as much as $66.02 \%$ of the total variation. The first component explains the most, about $20.88 \%$, whereas the sixth component explains $5.04 \%$ of the total variation. The remaining variance is explained by the other components. (See Table-3)

Table 3: Total Variance Explained

\begin{tabular}{clcc}
\hline Components & Eigenvalue & \% variation & Cumulative \% \\
\hline 1 & 4.18 & 20.88 & 20.88 \\
2 & 3.32 & 16.61 & 37.49 \\
3 & 1.86 & 9.32 & 46.81 \\
4 & 1.68 & 8.42 & 55.22 \\
5 & 1.15 & 5.75 & 60.98 \\
6 & 1.01 & 5.04 & 66.02 \\
\hline
\end{tabular}

Extraction Method: Principal Component Analysis (PCA).

Source: Author's field data, November 2015

The first component has significant loadings from 'the banners about the course offered by ICA $(G)$ on the road motivate me in selecting accounting as my choice of career' (0.790), 'the advertisements on accounting on television influenced me to choose accounting as my career' (0.917), 'the advertisements on accounting on radio influenced me to choose accounting as my career' (0.916) and 'the advertisements on accounting in the newspaper influenced me to choose accounting as my career' $(0.783)$. The four indicators have to do with career awareness programmes. Thus, this component may be interpreted as 'Influence of advertisement'.

The second receives high loadings from the indicators 'my career in accountancy is encouraged and recommended by my friends' $(0.705)$, 'my friends are pursuing or had pursued chartered accounting career' (0.689), and 'advice from friends pursuing or who had pursued a career in other fields' (0.784). These variables have to do with friends of the students. Hence, the second component may be interpreted as 'Peer influence'.

The third component has high loadings from 'prestige attached to the accounting profession' (0.708), 'expectation of high income after graduation' (0.771), 'I believe there is availability of jobs in the field of accounting' (0.720), and 'I would like to start my own practice/consultancy' (0.602). Thus, this component may be interpreted as 'Influence of Job prospects'.

Component four receives high loadings from 'parent's profession in accounting influenced me in selecting accounting career' (0.791), 'my family member who is an accountant advised me to choose accounting career' 
(0.797) and 'my parents persuaded me to choose accounting' (0.769). Hence, the fourth component may be interpreted as 'Parental/family influence'.

The fifth component has significant loadings from 'I like calculation based subjects rather than memorization-based subjects' $(0.686)$ and 'it is my ambition to become an accountant' (0.569). Thus, component five may be interpreted as 'Personal interest' determinant of career choice.

Lastly, has high loading from two variables, that is, 'my career in accountancy is encouraged and recommended by my teacher' $(0.822)$ and 'my teachers have interest in my career plan' (0.782). This component may be interpreted as 'Teacher influence'

Table 4: Factor loadings on determinants of career choice of accounting students

\begin{tabular}{|c|c|c|c|c|c|c|}
\hline \multirow[b]{2}{*}{ Variables } & \multirow[b]{2}{*}{1} & \multicolumn{5}{|c|}{ Component } \\
\hline & & 2 & 3 & 4 & 5 & 6 \\
\hline Like for calculation based subjects & & & & & .686 & \\
\hline Ambition to become an accountant & & & & & .569 & \\
\hline Nature of the accounting profession & & & & & & \\
\hline Prestige of the accounting profession & & & .708 & & & \\
\hline Parent's profession in accounting & & & & .791 & & \\
\hline Family member accountant & & & & .797 & & \\
\hline Parental persuasion & & & & .769 & & \\
\hline Friends encouragement & & .705 & & & & \\
\hline Accounting career of friends & & .689 & & & & \\
\hline Advice of friends in other fields & & .784 & & & & \\
\hline My teacher's encouragement & & & & & & 822 \\
\hline Teachers interest in my career plan & & & & & & .782 \\
\hline High income expectation & & & .771 & & & \\
\hline Availability jobs in accounting field & & & .720 & & & \\
\hline Desire to start my own audit practice & & & .602 & & & \\
\hline Participation in career programmes & & & & & & \\
\hline Banners about ICA $(\mathrm{G})$ courses & .790 & & & & & \\
\hline Advertisements on television & .917 & & & & & \\
\hline Advertisements on radio & .916 & & & & & \\
\hline Advertisements in the newspaper & .783 & & & & & \\
\hline
\end{tabular}

In order to determine which factors are most important in influencing the students' career choice in accounting, mean comparison was carried out as illustrated in Table 5. The table shows the mean and standard deviations of the career choice determinants for the total sample. As per the table, participants rated 'my ambition to become an accountant' (Mean=4.41) as the most important factor influencing their career choice decision, followed by 'like for calculation-based subjects rather than memorization based subjects' with the mean value of 4.13. These factors are mainly factors of personal interest. Thus, this study identified personal interest in accounting as the most important factor influencing the career choice among students of 
Institute of The Chartered Accountants (Ghana). Four other factors with high mean scores were 'expectation to earn high income' (Mean $=4.10$ ), 'availability of jobs in the field of accounting' (Mean = 4.02), 'the desire to start my own practice in auditing/consultancy' (Mean = 4.01) and 'prestige attached to the accounting profession' (Mean = 3.70). These factors were mainly factors of job prospects. The finding of this study is consistent with the work of Adams, Pryor \& Adams (1994), Strasser, Ozgur \& Schroeder (2002), and Umar (2014) who also found 'personal interest in the field', 'high earnings expectation', ‘job availability' and 'prestige' (high social status and respect for the profession) to be the most important factors in selecting accounting career. Thus, people choose the accounting profession based on their deep, personal interest and talents and not mainly because of money, status, and future career marketability as asserted by Surycz (2008). Students are also likely to choose a course of study, which they believe upon completion, would enhance their social status.

Factors relating to teachers' influence, namely: 'my teachers have interest in my career plan' and 'my teacher's encouraged and recommended my career' had mean scores above the average mean score of three (3) and were ranked eighth and ninth respectively. This indicates that teachers influence was important in influencing the career choice of the students. The author is in agreement with the comment of Marta Grygo (2003) that the support of teachers; including the teachers' beliefs and interest in students, encouragement and having a teacher as a role model, play an important role in students' career selection.

The mean scores of factors relating to Influence of advertisement, Peers and parents/family members were low. The mean scores of these factors were below the average mean score of three (3). This suggests that influences of advertisement, peers and parents or family members were considered least important by students in choosing their career in accounting. Thus, students make independent decision when it comes to choosing their desired course of study. They are not much affected by influences from peers, parents, or family members and advertisement. The findings of the present study is consistent with the work of Lowe \& Simons(1997) and Strasser, Ozgur \& Schroeder (2002) that the career choice of students were least influenced by the decision of their parents or family members, and friends. Advertisement (media and publicity) was also indentified as the least career influencing factor in the work of Ali \& Tinggi (2013). 
Table 5: Descriptive Statistics of Factors Influencing Students’ Accounting Career Choice

\begin{tabular}{|c|c|c|c|}
\hline No & Factors influencing career choice & $\begin{array}{l}\text { Mean } \\
\text { Score }\end{array}$ & $\begin{array}{l}\text { Standard } \\
\text { Deviation }\end{array}$ \\
\hline 1 & My ambition to become an accountant & 4.41 & .902 \\
\hline 2 & Like for calculation-based subjects rather than & & \\
\hline & memorization based subjects. & 4.13 & .937 \\
\hline 3 & $\begin{array}{l}\text { Expectation to earn high income after graduating in } \\
\text { accountancy programme }\end{array}$ & 4.10 & 1.005 \\
\hline 4 & Availability of jobs in the field of accounting & 4.02 & .975 \\
\hline 5 & $\begin{array}{c}\text { The desire to start my own practice in auditing / } \\
\text { consultancy }\end{array}$ & 4.01 & 1.101 \\
\hline 6 & $\begin{array}{l}\text { The challenging, interesting and satisfying nature of } \\
\text { the accounting profession }\end{array}$ & 3.99 & .974 \\
\hline 7 & Prestige attached to the accounting profession & 3.70 & 1.108 \\
\hline 8 & My teachers have interest in my career plan & 3.41 & 1.385 \\
\hline 9 & My teacher's encouraged and recommended my career & 3.14 & 1.396 \\
\hline 10 & Participation in career awareness programmes & 2.84 & 1.276 \\
\hline 11 & My friends pursing or had pursued accounting career & 2.76 & 1.372 \\
\hline 12 & Advice of friends in other career fields & 2.74 & 1.330 \\
\hline 13 & Encouragement and recommendation by my friends & 2.43 & 1.317 \\
\hline 14 & Banners about the course offered by ICA(G) & 2.28 & 1.228 \\
\hline 15 & Advertisements on accounting in the newspapers & 2.11 & 1.175 \\
\hline 16 & Advice of a family member who is an accountant & 2.10 & 1.309 \\
\hline 17 & Advertisements on accounting on television & 2.07 & 1.067 \\
\hline 18 & Advertisements on accounting on radio & 1.99 & 1.003 \\
\hline 19 & My parents profession in accounting & 1.95 & 1.260 \\
\hline 20 & Parental persuasion & 1.82 & 1.138 \\
\hline
\end{tabular}

Values are the means on a 5-point likert scale (strongly disagree $=1$, strongly agree $=5$ ) Source: Author’s field data, November 2015

Ultimately, different factors influence students' decision to choose a career in accounting as pointed out by Maharaj (2008). Several research studies had varying findings as to the factors that influenced students' career choice in accounting. Combining with the findings in this study, there is the need for educational researchers and professional bodies to discover the factors are that are really key influencers of students.

\section{Stage at which the accounting career decision was made}

Table-7 reveals that the majority of the participants (50.2\%) made their decision to pursue a career in accounting at the Senior High School Level, followed by $18.6 \%$ deciding when they were at Basic School (BS) Level. A small number of the participants at $3.2 \%$, decided to pursue accounting as a career at Master Degree level. 
Table 6: Stage at which the accounting career decision was made

\begin{tabular}{cc}
\hline Educational level & Percentage \\
\hline Basic School & 18.6 \\
SHS/'O' Level & 50.2 \\
Diploma/HND & 13.2 \\
First Degree & 14.8 \\
Others (Master Degree) & 3.2 \\
\hline Total & $\mathbf{1 0 0 . 0}$ \\
\hline
\end{tabular}

Source: Author's field data, November 2015

The findings of this research are inconsistent with those reported in earlier research studies. For example, Paolillo \& Estes, (1982) found that $23 \%$ of accounting majors made the decision at High School and $40 \%$ made the decision in their first year at the university. Mauldin , Crain \& Mounce, (2000) found that majority (41\%) of students chose accounting as their major during the first accounting course in college, followed by selection during High School (34 \%). Graves, Nelson \& Deines (1993) also reported that, one-third of the students they surveyed seriously considered a career in accounting while in High School. Clearly, it can be seen that decision to pursue accounting career is made earlier in the academic life of students in Ghana. The difference in the results regarding the timing of the decision to choose accounting as a career could be attributed to the sample used in these studies.

Making career decision at the Senior High School and Basic School levels may imply that the recruitment campaigns by professional accounting bodies at this stage of education are fairly effective. Ginzberg \& Associates, (1939) describe these levels as the tentative stage (11 - 18 years) of career development. During this stage, children begin their career consideration by asking themselves what their interests are and what they would like to do. The students at this level therefore need strong support and guidance of or from their parents, teachers and guidance and counselling officers to enable them make concrete and realistic decisions about the future career.

\section{Conclusion And Policy Implications}

The study used factor analysis to determine the major factors that influence the career decisions of the students. The study found out that personal and job prospect factors, such as students' interest in the accounting field, high earnings expectation, availability of jobs, prestige, and teacher influence were the most important factors that influence the career choice among students of the Institute of Chartered Accountants (Ghana). Less important factors include influences of advertisement, peers, and parents or family members. These findings call for students to be encouraged to choose careers based on their area of interest rather than imposing a career on them. 
Also teachers of accounting and other business related subjects at the preuniversity levels should make the learning of these subjects more interesting by assessing students' needs, tailoring the course experience, and using teaching techniques that purposefully heighten students' engagement. In addition, factors such as higher salaries, good working conditions, and job security being major influential forces in the career choice of accounting students called for policymakers and organisations' directors to take appropriate steps to improve working conditions in all sectors in order to attract and maintain young chartered accountants and other professionals.

The study also revealed that majority of the students, $50.2 \%$, made their decision to pursue a career in accounting at the Senior High School level. This is followed by $18.6 \%$ deciding when they were at Basic School. The remaining $37.2 \%$ of the students made their decision to pursue a career in accounting at the Diploma/HND, First Degree and Master Degree Levels. This shows that the decision to pursue accounting career is made earlier in the academic life of students in Ghana. A significant percentage of students deciding on their accounting career at an early stage in the Senior High School implies that accounting teachers at the Senior High School level and members of the accounting profession should increase the dissemination of information about accounting study and career opportunities to students at this level. Collaborative effort of the teachers, school administrators, and guidance counsellors at this level of education should also be made to comeup with better career plans for every individual student. In addition, a strong effort should be made by ICAG and other accounting bodies to promote the accounting profession to students in such a way that it is represented as a career choice of challenging opportunities, with a technical emphasis on decision- making roles, analysis and problem- solving, in addition to a welldeveloped generic skills. Lastly, government, companies, and accounting firms should support accounting education in Ghana and ensure that the programmes they support prove their worthiness by producing the right calibre of accounting graduates needed to perform the accounting functions in all sectors of the economy.

\section{Limitations Of The Study}

Even though this study supports several theoretical works on career choice, it has its own limitations that need to be acknowledged. The main limitation relates to the sampling method utilized. Due to time and financial constraints, the convenience sampling method was applied to students present on the particular dates that the researcher visited the various study centres. Probability sampling method, which could have given all the professional level students of the Institute the chance of being included in the sample, was not possible. As a result, the current study cannot be generalized 
to the entire ICAG professional level student population in Ghana. The results of the study may only be generalized to a sample that includes ICAG professional level students living in Greater Accra, Volta Region and part of the Eastern Region of Ghana. Future studies should include students of other registered professional accounting bodies operating in Ghana such as Association of Certified Chartered Accountants (ACCA), and Chartered Institute of Management Accountants (CIMA) as the factors influencing career choice in accounting may vary considerably among these group of students.

\section{References:}

1. Adams, S. J., Pryor, L. J., and Adams, S. L., (1994). 'Attraction and retention of high-aptitude students in accounting': An exploratory longitudinal study. Issues in Accounting.

2. Adeleke, M. S., Adeyinka, S. F., and Kofoworade, A. D., (2012). Determinants of vocational interests and academic career choice performance among business education teacher trainees of colleges of education in Oyo State, Nigeria. Journal of Education, 2(2),197- 207

3. Ahinful G. S., Paintsil, R. O., \& Danquah J. B., (2012). Factors influencing the choice of accounting as a major in Ghanaian Universities. Journal of Education and Practice, ISSN 2222-1735 (Paper) ISSN 2222-288X (Online) Vol 3, No 15.

4. Ahmed, K., Alam, K. F., and Alam, M., (1997). An empirical study of factors affecting accounting students' career choice in New Zealand, Accounting Education: an international journal, 6(4), pp. 325-335.

5. Albrecht, W. S., and Sack, R. J., (2000). Accounting Education: Charting the course through a perilous future. Accounting Education Series, Vol. 16. Sarasota, FL: American Accounting Association.

6. Ali S.S., \& Tinggi M., (2013). Factors influencing the students' choice of accounting as a major. The IUP Journal of Accounting Research \& Audit Practices, Vol. XII, No. 4, 201326

7. Angela, Walmsley, Travis, W., \& Courtney, M., (2010). Influences on a college student's major: A developmental perspective. Journal for the Liberal Arts and Sciences, 14(2), 25 - 46.

8. Carpenter, C. G., and Strawser, R. H., (1970). Job selection preferences of accounting students, The Journal of Accountancy, 129(6), pp. 84-86.

9. Cohen, J., and Hanno, D. M., (1993). An analysis of underlying constructs affecting the choice of accounting as a major, Issues in Accounting Education, 8(2), pp. 219-238. 
10. Djatej A., Chen Y., Scott E. and Zhou D., (2015). Understanding students' major choice in accounting: an application of the theory of reasoned action. Global Perspectives on Accounting Education, Volume 12, 2015, 53-72

11. Edwards, K., and Quinter M., (2011). Factors influencing students' career choices among secondary school students in Kisumu Municipality, Kenya. Journal of Emerging Trends in Educational Research and Policy Studies (JETERAPS) 2 (2): 81-87.Education, 9, 45-58.

12. Fabea, Ineke Bossman, (2014). Educational factors that influence the career choices of University of Cape Coast Students, International Journal of Research in Social Sciences Vol. 4, No.2

13. Fatoki O., (2014). The determinants of the career choice of international students in South Africa. Mediterranean Journal of Social Sciences, Vol 5 No 23

14. Felton, S., Buhr, N., and Northey, M., (1994). Factors influencing the business student's choice of a career in chartered accountancy, Issues in Accounting Education, 9(1), pp. 131-141.

15. Field, A., (2005). Discovering Statistics Using SPSS. London: SAGE Publications.

16. Financial Reporting Council (FRC), (2015). Key Facts and Trends in the Accountancy Profession. Accessed on July 15, 2016 from https://www.frc.org.uk/Our Work /Publications / ProfessionalOversight/Key-Facts-and-Trends-in-the-Accountancy-Profes-(1).pdf

17. Ghani E. K., Said J., Nasir N.M. \& Jusoff K., (2008). The $21^{\text {st }}$ Century accounting career from the perspective of the Malaysian University students, Asian Social Science, Vol. 4, No. 8

18. Grygo M., (2003). An examination of selected factors influencing the career decisions of aboriginal university students. University of Lethbridge (Canada) 0494174005, 9780494174005

19. Hall, D. T., (1996). Protean careers of the $21^{\text {st }}$ Century. The Academy of Management Executive, 10(4), 8-16.

20. Hashim H. M., and Embong A.M., (2015). Parental and peer influences upon accounting as a subject and accountancy as a career. Journal of Economics, Business and Management, Vol. 3, No. 2.

21. Jackling, B., (2002). Are negative perceptions of the accounting profession perpetuated by the introductory accounting course? An Australian study, Asian Review of Accounting, Vol. 10 No. 2, pp. 6280.

22. Joseph B. F., (2013). Factors influencing the selection of business studies: A comparative study of Indian students at an Indian 
University and Chinese students at a Thai University. AU-GSB eJournal, Vol. 6, No 1

23. Marshall, R. (2003). "Calling on tomorrow's professionals", Chartered Accountants' Journal,

24. Vol. 82 No. 1, pp. 4-9.

25. Mauldin S., Crain J. L., and Mounce P. H., 2000). “The accounting principles instructor's influence on student's decision to major in accounting," Journal of Education for Business, vol. 75, no. 3, pp. $142-148$

26. Mbawuni J., (2015). Examining students' feelings and perceptions of accounting profession in a developing country: The role of gender and student category. International Education Studies; Vol. 8, No. 6; ISSN 1913-9020 E-ISSN 1913-9039

27. Nelson, I.T., Vendrsyk, V.P., Quirin, J.J., \& Allen, R.D., (2002). No, the sky is not falling: Evidence of accounting student characteristics at FSA schools, 1995-2000. Issues in Accounting Education, 17(3):269-287.

28. Ohiwerei, F.O., and Nwosu, B. O., (2009). Vocational choices among secondary school students: Issues and strategies in Nigeria. Asian Journal of Business Management 1(1): 1-5,

29. Osipow, S. H., (2003). Theories of career development. New York: Prentice Hall.

30. Oyebode, M. O., (1980). "The influence of parental education on the level of vocational aspiration of class three and four students of Lagos area,” presented at the Nigerian Psychological Conference, Lagos, Nigeria,

31. Paolillo, J.G.P, and Estes R.W., (1982). An empirical analysis of career choice factors among accountants, attorneys, engineers and physicians. The Accounting Review 57, no. 4, pp. 785-793

32. Salami, S.O., (2006). Influence of culture, family and individual differences on choice of gender-dominated occupations among female students in tertiary institutions. Gender and Behaviour, 4(2): 814- 833.

33. Sharf, R.S., (1997). Applying career development theory to counseling. ( $2^{\text {nd }}$ Ed). Pacific

34. Grove, CA: Brooks/Cole

35. Simons, K., Lowe D. R., and Stout D. E., (2003). "Comprehensive literature review: Factors influencing choice of accounting as a major”, Proceedings of the 2003 Academy of Business Education Conference, Vol. 4.

36. Strasser, S.E., Ozgur, C., and Schroeder, D.L., (2002). Selecting a business college major: Ananalysis of criteria and choice using the 
analytical hierarchy process. Mid-American Journal of Business, 17, 47-56.

37. Sugahara S., and Boland, G., (2009). The accounting profession as a career choice for tertiary business students in Japan-A factor analysis. Accounting Education: An international journal, Vol. 18, No. 3, 255-272.

38. Umar, I., (2014). Factors influencing students' career choice in accounting: The case of Yobe State University. Research Journal of Finance and Accounting, ISSN 2222-1697 (Paper) ISSN 2222-2847 (Online) Vol.5, No.17.

39. Uyar A., \& Ali, H. G., (2011). Factors affecting students' career choice in accounting: The case of Turkish University. American Journal of Business Education, 4 (1), 29-38.

40. Topan R. (2014) Considering a Career in Accounting? Here's What You Need to Know. Accessed on June 20, 2015 from http ://talentegg.ca/incubator/2014/09/08/career-accounting-heres/ 


\section{APPENDIX A}

Correlation among the twenty Indicator Variables

\begin{tabular}{|c|c|c|c|c|c|c|c|c|c|c|c|c|c|c|c|c|c|c|c|c|}
\hline & $\mathrm{X} 1$ & $\mathrm{X} 2$ & X3 & $\mathrm{X} 4$ & X5 & X6 & $\mathrm{X7}$ & X8 & X9 & $\mathrm{X} 10$ & $\mathrm{X} 11$ & $\mathrm{X} 12$ & $\mathrm{X} 13$ & $\mathrm{X} 14$ & $\mathrm{X} 15$ & X16 & $\mathrm{X} 17$ & $\mathrm{X} 18$ & X19 & $\mathrm{X} 20$ \\
\hline $\mathrm{X} 1$ & 1.00 & & & & & & & & & & & & & & & & & & & \\
\hline X2 & 0.32 & 1.00 & & & & & & & & & & & & & & & & & & \\
\hline X3 & 0.13 & 0.43 & 1.00 & & & & & & & & & & & & & & & & & \\
\hline $\mathrm{X} 4$ & 0.04 & 0.22 & 0.18 & 1.00 & & & & & & & & & & & & & & & & \\
\hline X5 & -0.13 & -0.13 & 0.00 & 0.08 & 1.00 & & & & & & & & & & & & & & & \\
\hline X6 & -0.04 & -0.09 & -0.09 & 0.06 & 0.44 & 1.00 & & & & & & & & & & & & & & \\
\hline X7 & -0.13 & -0.23 & -0.14 & 0.01 & 0.54 & 0.43 & 1.00 & & & & & & & & & & & & & \\
\hline X8 & -0.02 & 0.07 & 0.05 & 0.01 & 0.13 & 0.11 & 0.14 & 1.00 & & & & & & & & & & & & \\
\hline X9 & 0.09 & 0.20 & 0.11 & 0.03 & 0.12 & 0.03 & 0.05 & 0.61 & 1.00 & & & & & & & & & & & \\
\hline X10 & 0.01 & 0.06 & 0.09 & 0.08 & 0.09 & 0.08 & 0.08 & 0.37 & 0.39 & 1.00 & & & & & & & & & & \\
\hline X11 & 0.02 & 0.19 & 0.11 & 0.11 & 0.03 & -0.02 & 0.07 & 0.41 & 0.44 & 0.70 & 1.00 & & & & & & & & & \\
\hline $\mathrm{X} 12$ & 0.04 & 0.07 & 0.02 & 0.02 & 0.05 & 0.01 & 0.06 & 0.15 & 0.24 & 0.20 & 0.25 & 1.00 & & & & & & & & \\
\hline X13 & 0.19 & 0.35 & 0.28 & 0.41 & -0.03 & 0.04 & -0.09 & 0.06 & 0.16 & 0.11 & 0.18 & 0.09 & 1.00 & & & & & & & \\
\hline X14 & 0.19 & 0.38 & 0.33 & 0.32 & 0.01 & 0.02 & -0.09 & 0.15 & 0.22 & 0.15 & 0.23 & 0.15 & 0.64 & 1.00 & & & & & & \\
\hline X15 & 0.11 & 0.34 & 0.43 & 0.27 & -0.01 & -0.01 & -0.11 & 0.05 & 0.05 & 0.17 & 0.23 & -0.12 & 0.40 & 0.45 & 1.00 & & & & & \\
\hline X16 & 0.00 & 0.12 & 0.06 & 0.12 & 0.01 & -0.07 & 0.06 & 0.24 & 0.18 & 0.29 & 0.43 & 0.04 & 0.13 & 0.29 & 0.20 & 1.00 & & & & \\
\hline X17 & -0.05 & -0.03 & -0.07 & 0.14 & 0.19 & 0.13 & 0.15 & 0.17 & 0.14 & 0.20 & 0.20 & 0.05 & 0.06 & 0.11 & 0.00 & 0.37 & 1.00 & & & \\
\hline X18 & -0.07 & -0.05 & -0.03 & 0.05 & 0.21 & 0.14 & 0.31 & 0.26 & 0.14 & 0.19 & 0.16 & 0.04 & 0.05 & 0.12 & 0.00 & 0.31 & 0.71 & 1.00 & & \\
\hline X19 & -0.07 & -0.14 & -0.09 & 0.03 & 0.19 & 0.15 & 0.26 & 0.24 & 0.13 & 0.14 & 0.14 & 0.05 & 0.04 & 0.11 & -0.02 & 0.30 & 0.64 & 0.86 & 1.00 & \\
\hline X20 & -0.02 & -0.06 & -0.05 & 0.01 & 0.13 & 0.08 & 0.23 & 0.29 & 0.15 & 0.23 & 0.20 & 0.05 & 0.02 & 0.08 & 0.06 & 0.23 & 0.49 & 0.66 & 0.69 & 1.00 \\
\hline
\end{tabular}

